\title{
Inovasi Pemerintahan dan Pelaku Usaha Batik Jumputan dalam Pengembangan Industri Kreatif di Masa Pandemi Covid-19 (Studi Kasus Kampung Tahunan Yogyakarta)
}

\author{
Ayu Pingkan Nayuni', Bachtiar Dwi Kurniawan² \\ ${ }^{1,2}$ Universitas Muhammadiyah Yogyakarta, Daerah Istimewa Yogyakarta, Indonesia \\ ${ }^{1}$ Email: ayupingkan6@gmail.com
}

\begin{abstract}
Abstrak: Penelitian ini bertujuan untuk mendeskripsikan dan menguraikan secara terperinci bagaimana inovasi yang dilakukan oleh Dinas Kopukmnakertrans dan pelaku usaha dalam mengembangkan industri kreatif batik jumputan pada masa pandemi Covid-19. Penelitian ini menggunakan metode kualitatif dengan tipe penelitian deskriptif. Teknik pengumpulan data dilakukan melalui observasi, wawancara, dan dokumentasi. Berdasarkan penelitian yang telah dilakukan bahwa inovasi yang dilakukan Dinas Kopukmnakertrans adalah mengikuti dengan kondisi pandemi Covid-19 saat ini dengan mengadakan pameran dan pelatihan. Dan inovasi yang dilakukan pelaku usaha batik jumputan telah dilakukan dengan sangat baik yaitu terdapatnya beberapa manfaat bagi pelaku usaha pada masa pandemi Covid-19, terdapat kesesuain dengan kebutuhan masyarakat, memeliki tingkat kerumitan yang rendah, dan telah dilakukan uji publik terlebih dahulu serta keberhasilan dari inovasi yang dilakukan pelaku usaha batik jumputan dapat mudah diamati. Sedangkan untuk hambatan dalam melakukan inovasi antara lain: berkurangnya tenaga kerja, berkurangnya kegiatan produksi akibat pandemi Covid-19 dan hambatan modal dari pemerintah.
\end{abstract}

Kata Kunci: Inovasi, Pelaku Usaha, Batik Jumputan, Industri Kreatif.

Abstract: This study aims to describe and describe in detail how the innovations carried out by the Kopukmnakertrans Service and business actors in developing the jumputan batik creative industry during the Covid-19 pandemic. This research uses qualitative method with descriptive research type. Data collection techniques were carried out through observation, interviews, and documentation. Based on the research that has been done, the innovation made by the Kopukmnakertrans Service is to follow the current Covid-19 pandemic conditions by holding exhibitions and training. And the innovations carried out by the Jumputan batik business actors have been carried out very well, namely there are several benefits for business actors during the Covid-19 pandemic, there is compatibility with community needs, has a low level of complexity, and public testing has been carried out first and the success of the innovation. What the jumputan batik business actors do can be easily observed. As for the barriers to innovation, among others: reduced workforce, reduced production activities due to the Covid-19 pandemic and capital constraints from the government.

Keywords: Innovation, Business Actor, Jumputan Batik, Creative Industry.

Article History:

Received : 2020-05-14

Revised : 2020-6-16

Accepted : 2020-7-20

\section{PENDAHULUAN}

Studi ini menganalisa mengenai inovasi yang dilakukan Dinas Kopukmnakertrans Kota Yogyakarta dan pelaku usaha dalam mengembangkan industri kreatif batik jumputan pada masa pandemi Covid-19. Pengelolaan batik jumputan di Kampung ini terlihat dengan banyaknya pengrajin dan banyaknya sumber daya manusia yang inovatif yang mampu menciptakan batik jumputan yang berbeda dengan produsen lainnya.

Saat ini, berbagai sektor industri telah berkembang pesat di berbagai belahan dunia. Salah satunya pada sektor industri kreatif, sektor industri kreatif dianggap mampu dan berpengaruh terhadap kesejahteraan masyarakat. Pada zaman yang serba modern sekarang ini, kreatifitas merupakan syarat utama yang harus dimiliki manusia sebagai bentuk pemenuhan kebutuhan dan kreatifitas memiliki potensi ekonomi melalui pengetahuan produksi yang inovatif. Maka dari itu, setiap manusia diharapkan mampu beradaptasi dan mengikuti arus perkembangan industri yang kian maju dan kreatif. Industri kreatif sangat erat hubungannya dengan 
perekonomian masyarakat dimana industri ini merupakan wadah bagi para pelaku usaha untuk berkembang pesat.

Di berbagai daerah di Indonesia, industri kreatif sudah berkembang pesat. Salah satunya di Kota Yogyakarta. Kota Yogyakarta sendiri merupakan kota yang sangat kental dengan budaya dan tradisinya. Banyak UMKM di Kota Yogyakarta yang masih menanamkan nilai budaya dalam memproduksi suatu barang atau jasa. Tak heran jika Kota Yogyakarta mempunyai misi meningkatkan kualitas pendidikan, kesehatan, sosial dan budaya. Kerajinan khas dari kota ini yang terkenal di berbagai pelosok negeri hingga mancanegara ialah kain batik. Perkembangan batik di Kota Yogyakarta sendiri telah memikat wisatawan untuk berkunjung ke kota ini. Kain batik mempunyai ribuan motif yang dipasarkan, salah satunya batik jumputan.

Batik jumputan merupakan batik yang dalam pengerjaannya menggunakan teknik ikat celup, batik ini berbeda dengan batik pada umumnya. Jika batik lainnya menggunakan malam untuk proses pewarnaan, batik jumputan untuk proses pewarnaan menggunakan kainnya itu sendiri. Yakni dengan kain yang diikat atau dijahit atau dikerut dengan menggunakan tali, tali ini nantinya berfungsi untuk menutupi bagian agar tidak terkena warna.

Batik jumputan sudah sangat terkenal di Kota Yogyakarta dan menariknya di kota ini batik jumputan ini memiliki kampung sentral pengrajin yang mana sebagian besar penduduk di kampung ini memproduksi kain batik jumputan. Kampung Tahunan yang terletak di Kecamatan Umbulharjo Kota Yogyakarta ini memproduksi kain Batik Jumputan sejak tahun 2010. Kampung Tahunan ini sudah ditetapkan menjadi kampung wisata oleh pemerintah kota. Di kampung ini terdapat berbagai macam home industry, kesenian, berbagai ragam souvenir, dan usaha kuliner. Batik jumputan yang diproduksi oleh penduduk kampung tahunan merupakan produk keunggulan dan kebanggaan Kampung Tahunan Umbulharjo (Juwita, 2018).

Tahun 2020 menjadi tahun yang sangat memberikan dampak besar bagi sebagian besar negara. Tahun ini dunia sedang menghadapi Corona Virus Disease atau yang lebih dikenal dengan COVID-19. COVID-19 sendiri merupakan coronavirus jenis baru yang ditemukan di Wuhan, Hubei, China pada tahun 2019. Karena itu, Coronavirus jenis baru ini diberi nama Coronavirus disease-2019 yang disingkat menjadi COVID-19. COVID-19 sejak ditemukan menyebar secara luas hingga mengakibatkan pandemi global yang berlangsung sampai saat ini (Amri, 2020).

Pengrajin lokal seperti pengrajin batik jumputan juga tidak luput dari dampak yang dirasakan yakni dengan omset penjualan yang menurun. Dari tahun 2019 rata-rata pelaku usaha mampu menjual produknya dari 300pcs-1000pcs akan tetapi setelah adanya Covid-19 pelaku usaha batik jumputan hanya mampu menjual setengahnya.

Pada saat sebelum pandemi pelaku usaha batik jumputan mampu memasarkan produknya di berbagai acara pameran yang diselenggarakan oleh pemerintah Kota Yogyakarta dan mengikuti fashion show. Biasanya satu pelaku usaha industri batik jumputan mampu memproduksi sekitar 2-3 hari sekali namun sejak adanya pandemi Covid-19 hanya mampu memproduksi satu kali dalam seminggu. Maka dari itu peneliti sangat tertarik untuk meniliti bagaimana "Inovasi Pelaku Usaha Batik Jumputan dalam Pengembangan Industri Kreatif di Masa Pandemi dengan Studi Kasus di Kampung Batik Jumputan Tahunan Umbulharjo Kota Yogyakarta".

\section{METODE PENELITIAN}

Berdasarkan masalah yang dibahas dalam penelitian yang menitikberatkan pada makna dan nilai-nilai, maka metode yang digunakan dalam penelitian ini menggunakan metode penelitian kualitatif secara sistematis dan mendalam mengenai inovasi pemerintah Kota Yogyakarta dan kelompok usaha batik jumputan dalam pengembangan industri kreatif di masa 
pandemi Covid-19. Penelitian ini berlokasi di Kota Yogyakarta yang merupakan Kota berwawasan budaya sehingga menghasilkan berbagai seni tradisional. Penelitian dilaksanakan di Kampung Tahunan, Kecamatan Umbulharjo, Kota Yogyakarta dimana kampung ini merupakan sentral pengrajin batik jumputan. Teknik pengumpulan data dalam penelitian ini melalui wawancara dengan staff Dinas Kopukmnakertrans Kota Yogyakarta dan beberapa owner butik batik jumputan dan melalui laporan-laporan, buku catatan, dan dokumentasi lainnya.

\section{Inovasi Pemerintahan}

\section{HASIL DAN PEMBAHASAN}

Inovasi Pemerintahan menurut Rogers terdiri dari dua tahap, yaitu: Tahap Initiation atau Perintisan dan Tahap Implementasi. Tahapan perintisan terdiri atas fase agenda setting dan matching. Ini merupakan tahapan awal pengenalan situasi dan pemahaman permasalahan yang terjadi dalam organisasi. Sedangkan pada tahapan implementasi, perintisan telah menghasilkan keputusan untuk mencari dan menerima inovasi yang dianggap dapat menyelesaikan permasalahan organisasi. Tahapan implemenasi ini terdiri atas fase redefinisi, klarifikasi dan rutinisasi.

Pada tahap initiation atau perintisan dalam melakukan inovasi pengembangan industri kreatif pada masa pandemi Covid-19, wawancara dan penelitian yang dilakukan dengan salah satu staff Dinas Kopukmnakertrans dapat disimpulkan bahwa, Dinas Kopukmnakertrans Kota Yogyakarta melakukan program inovasi tidak secara langsung ketika pandemi Covid-19 datang melainkan melakukan penyesuaian terhadap kondisi yang ada yakni memulai program pada sekitar bulan Agustus dan September 2020.

Pada tahapan implementasi, perintisan telah menghasilkan keputusan untuk mencari dan menerima inovasi yang dianggap dapat menyelesaikan permasalahan organisasi. Tahapan implemenasi ini terdiri atas fase redefinisi, klarifikasi dan rutinisasi. Pada fase redefinisi, seluruh inovasi yang diadopsi mulai kehilangan karakter asingnya. Inovasi sudah melewati proses re-invention, sehingga lebih dekat dalam mengakomodasi kebutuhan organisasi. Dari wawancara dan penelitian yang telah dilakukan bahwa Dinas Kopukmnakertrans Kota Yogyakarta melakukan program inovasi mengadakan mengadakan kegiatan pameran yang bekerjasama dengan perusahaan swasta yakni Lippo Mall Group untuk memfasilitasi pelaku usaha untuk mempromosikan usahanya dalam pameran yang dilaksanakan di Lippo Mall.

Pada tahap klarifikasi diketahui bahwa Dinas Kopukmnakertrans Kota Yogyakarta menyusun ulang rencana anggaran untuk Program Covid-19 yaitu menggunakan dana tak terduga dari BPBD Kota Yogyakarta untuk mengadakan pameran UMKM pada bulan November 2020 dan menggunakan dana keistimewaan untuk mengadakan pelatihan UMKM.

\section{Inovasi Pelaku Usaha}

Proses inovasi dan hambatan inovasi yang dilakukan pelaku usaha batik jumputan melalui tahapan yang sesuai dengan karakteristik inovasi: Relative Advantage, Compatibility, Kompleksitas, Trialibility, dan Observability. Inovasi yang dilakukan oleh pelaku usaha batik jumpuutan terdiri dari inovasi produk dan inovasi pemasaran

Relative Advantage, merupakan kadar atau tingkat sebuah inovasi dipersepsikan lebih baik daripada ide inovasi sebelumnya. Biasanya keuntungan relatif diukur dalam terminologi ekonomi, tetapi faktor prestise sosial, kenyamanan, dan kepuasan sering menjadi komponen yang tak kalah penting. Semakin banyak keunggulan relatif yang dirasakan sebuah inovasi, maka akan semakin cepat laju tingkat adopsinya (Rogers, 1983). Pada tahap ini inovasi yang dilakukan oleh pelaku usaha batik jumputan memberikan beberapa manfaat yaitu meningkatkan kualitas, memenuhi kebutuhan masyarakat, menciptakan produk baru, 
meningkatkan efisiensi produk, dan menciptakan pasar baru melalui platform Shopee, Instagram, Tokopedia, dan Whatsapp.

Compatibility, merupakan tingkat sebuah inovasi dipersepsikan konsisten dengan nilainilai yang sudah ada, pengalaman masa lalu, serta sesuai dengan kebutuhan orang-orang. Kesesuaian pada inovasi produk yang dilakukan oleh pelaku usaha batik jumputan adalah mencoba mengikuti kebutuhan masyarakat selama pandemi Covid-19 yang dianjurkan untuk mentaati protokol kesehatan 3M (Memakai masker, Menjauhi kerumunan, Mencuci tangan). Kesesuaian pada inovasi pemasaran yang dilakukan oleh pelaku usaha batik jumputan sudah sangat sesuai dengan yang dibutuhkan oleh masyarakat selama masa pandemi Covid-19 yakni kemudahan mengakses, kecepatan mengakses, dan aman.

Kompleksitas, merupakan indikator ketiga yang terdapat dalam inovasi yang digunakan untuk mengetahui tingkat kerumitan dari adanya inovasi tersebut. Bagi pelaku usaha batik jumputan kesederhanaan dalam melakukan inovasi pemasaran online sangatlah mudah dan efektif, dimana yang dibutuhkan hanya jaringan internet yang stabil dan smartphone. Akan tetapi dalam melakukan inovasi pada masa pandemi Covid-19 terdapat beberapa hambatan yakni: berkurangnya tenaga kerja, berkurangnya produksi, dan minimnya bantuan dari pemerintah.

Trialibility, merupakan indikator ke empat dari inovasi yang digunakan untuk menjelaskan bahwa inovasi hanya bisa diterima apabila telah teruji dan terbukti mempunyai keuntungan. Inovasi yang dilakukan pelaku usaha batik jumputan telah melewati tahap uji coba guna mengukur dan memenuhi tingkat kebutuhan masyarakat selama masa pandemi Covid-19. Inovasi yang dilakukan pelaku usaha batik jumputan yakni inovasi produk yang ramah kantong dan inovasi pemasaran online telah diberlakukan sejak awal pandemi Covid-19 yakni pada bulan Juni 2020. Inovasi pemasaran online telah dilakukan uji coba sejak tahun 2018, pemasaran online ini sejak 3 tahun lalu dilakukan untuk memenuhi kebutuhan masyarakat yang sedang marak belanja online namun pada awal diberlakukannya sistem pemasaran online ini belum berkembang secara pesat.

Observability, merupakan tingkat di mana sebuah inovasi itu kelihatan bagi orang lain. Semakin mudah bagi individu untuk melihat hasil sebuah inovasi, maka semakin besar kemungkinan mereka untuk mengadopsinya. Keberhasilan dari adanya inovasi yang dilakukan pelaku usaha batik jumputan pada masa pandemi Covid-19 ini juga dapat diamati dengan mudah yaitu dari kemudahan akses yang dirasakan masyarakat dan pelaku usaha batik jumputan itu sendiri dalam memperkenalkan karyanya melalui event pameran, serta pemasaran online yang dapat menjangkau semua kalangan masyarakat.

\section{Industri Kreatif Batik Jumputan Kerajinan Batik Jumputan}

Kelurahan Tahunan sendiri mempunyai produk kerajinan yang yang menjadi keunggulan kelurahan ini dan menjadi daya tarik wisatawan yakni kerajinan batik jumputan. Kampung Tahunan ini memiliki beberapa home industri seperti Kain Jumputan Ibu Sejahtera, Batik Jumput Batikan, Sanggar Jumputan Maharani, Batik Jumputan Hanna, Dea Modis. Kerajinan batik jumputan di Kampung Tahunan ini sudah menjadi identitas bagi kampung itu sendiri bahkan sudah menjadi kampung wisata dengan berbagai macam seni dan kerajinan, kerajinan batik jumputan di Kampung Tahunan ini sudah berkembang pesat, salah satunya dengan adanya beberapa kelompok usaha.

Perkembangan kerajinan batik jumputan ini terlihat pada aktivitas para kelompok usaha batik jumputan dan pelaku usaha batik jumputan yang tidak berhenti berinovasi. Pandemi Covid-19 tidak mematahkan semangat para pelaku usaha batik jumputan ini, salah satu kegiatan untuk mengembangkan bisnis ini adalah pelatihan dan seminar tentang batik jumputan namun yang aktif sampai sekarang adalah pelatihan saja dikarenakan pandemi Covid-19. 


\section{Fashion Batik Jumputan}

Perkembangan fashion batik jumputan yang ada di Kampung Tahunan ini ditujukan dengan berbagai acara yang diikuti yang diselenggarakan oleh pemerintah Kota Yogyakarta maupun dari komunitas-komunitas. Sejak adanya pandemi Covid-19 pelaku usaha mengembangkan berbagai mode batik jumputan, salah satunya adalah membuat inovasi produk baru yakni masker, kaos oblong, dan sajadah. Menjalankan inovasi produk pada saat pandemi Covid-19 sangat terbantu dengan adanya event pameran. Sebelum pandemi Covid-19 memperkenalkan mode batik jumputan juga dengan mengikuti ajang fashion show yang mana diselenggarakan oleh pemerintah.

\section{KESIMPULAN DAN SARAN}

Berdasarkan hasil penelitian mengenai inovasi pemerintahan, dapat ditarik kesimpulan bahwa selama pandemi ini Dinas Kopukmnakertrans memulai action untuk menyesuaikan dengan keadaan pandemi Covid-19 pada bulan Agustus 2020 dengan mengadakan pameran di Lippo Mall. Dan inovasi yang dilakukan oleh Dinas Kopukmnakertrans dikatakan berhasil dilihat dari program pelatihan dan pameran untuk UMKM yang diselenggarakan secara rutin selama pandemi Covid-19 berlangsung. Upaya inovasi pelaku usaha batik jumputan dalam mengembangkan industri kreatif telah dilakukan dengan baik. Hal ini bisa dilihat dari penelitian kelima karakteristik inovasi yang telah dilakukan peneliti. Namun ada beberapa hambatan yakni berkurangnya tenaga kerja, berkurangnya produksi, dan minimnya bantuan dari pemerintah.

Berdasarkan hasil penelitian mengenai industri kreatif batik jumputan khususnya di Kelurahan Tahunan dalam hal kerajinan sudah berkembang dengan baik dengan adanya beberapa program kegiatan yang dilakukan kelompok usaha batik jumputan. Saran yang dapat peneliti sampaikan adalah Perlu adanya evaluasi kembali terkait bantuandari pemerintah agar lebih dipermudah dalam prosedurnya sehingga tidak berbelit-belit dan efektif. Menjaga konsistensi dari inovasi yang dilakukan agar kepercayaan dari masyarakat terhadap penilaian tersebut dapat tetap dipertahankan. Pelaku usaha agar tidak cepat berpuas diri dan mengevaluasi dari inovasi yang dilakukan serta tidak berhenti melakukan inovasi sehingga dapat menambah daya tarik konsumen.

\section{DAFTAR PUSTAKA}

Amri, A. (2020). Dampak Covid-19 Terhadap UMKM di Indonesia. Jurnal Brand, 2(1), 147153. Retrieved from https://www.academia.edu/42672824/Dampak_Covid19_Terhadap_UMKM_di_Indonesia

Ananda, A. D., \& Susilowati, D. (2019). Pengembangan Usaha Mikro Kecil dan Menengah (UMKM) Berbasis Industri Kreatif di Kota Malang. Jurnal Ilmu Hukumrnal Ilmu Ekonomi, X(X), 120-142.

Anjaningrum, W. D., \& Sidi, A. P. (2018a). Kreatifitas dan inovasi produk industri kreatif. Conference on Innovation and Application of Science and Technology, (September), 6170 .

Anjaningrum, W. D., \& Sidi, A. P. (2018b). Pengaruh Orientasi Pasar, Inovasi Dan Kreativitas Produk Terhadap Kinerja Industri Kreatif Untuk Mencapai Keunggulan Bersaing. Jurnal Ilmiah Bisnis Dan Ekonomi Asia, 12(2), 30-47. https://doi.org/10.32812/jibeka.v12i2.22

Arifianto, E. Y. (2018). STRATEGI PENGEMBANGAN INDUSTRI KREATIF KERAJINAN TOPENG ERA INDUSTRI 4.0. Seminar Nasional IENACO.

Fitriana, A. N., Noor, I., Hayat, A., Publik, J. A., Administrasi, F. I., \& Brawijaya, U. (n.d.). PENGEMBANGAN INDUSTRI KREATIF DI KOTA BATU ( Studi tentang Industri Kreatif 
Sektor Kerajinan di Kota Batu ). 2(2), 281-286.

Helaluddin, \& Wijaya, H. (2019). Analisis Data Kualitatif: Sebuah Tinjauan Teori \& Praktik. Sekolah Tinggi Theologia Jaffray.

Juwita, H. K. (2018). Kain Jumputan di Kampung Tahunan Umbulharjo Yogyakarta. Pendidikan Kriya, (2), 230-239. Retrieved from http://eprints.uny.ac.id/57463/1/HesaKurniaJuwita\%2813207244007\%29.pdf

Lingga, M. A. (2019). Industri Kreatif Punya Kontribusi pada Pertumbuhan Ekonomi Indonesia. Kompas.Com. Retrieved from https://money.kompas.com/read/2019/08/16/204100026/industri-kreatif-punyakontribusi-pada-pertumbuhan-ekonomi-indonesia

Maharani, A., \& Sumowo, S. (2019). Inovasi Kue Batik Jember Sebagai Upaya Pengembangan Industri Ekonomi Kreatif Berbasis Kearifan Lokal Jember. CARADDE: Jurnal Pengabdian Kepada Masyarakat, 2(2), 193-202. https://doi.org/10.31960/caradde.v2i2.312

Poerwanto. (2012). Inovasi Produk dan Motif Seni Batik Pesisiran Sebagai Basis Pengembangan Industri Kreatif Dan Kampung Wisata Minat Khusus. AL-AZHAR INDONESIA SERI PRANATA SOSIAL, 1 .

Prayudi. (2020). Analisis Kota Yogyakarta Sebagai Kota Kreatif: Pendekatan Sinergitas Quadro Helix. Jurnal EKSOS, 2(2), 94-105.

Raldianingrat, W., \& Wuryanti. (2014). Upaya Peningkatan Kineja Industri Kreatif Kerajinan Melalui People Equity Dan Strategi Inovasi Di Kabupaten Konawe. Ekobis, 15(2), 102112. Retrieved from http://jurnal.unissula.ac.id/index.php/ekobis/article/viewFile/566/468

Rifa'i, M., \& Sasongko, T. (2019). Meningkatkan Keunggulan Bersaing Produk melalui Inovasi dan Orientasi Pasar pada Usaha Sektor Industri Kreatif di Kota Malang. $J$ u $r n$ a $l E K B I S, x x$.

Sari, L. F. (2018). Strategi Inovasi Produk Pada Industri Kreatif Minangkabau Untuk Mengatasi Pengangguran Di Sumatera Barat. https://doi.org/10.31227/osf.io/wq6jb

Sasono, E. (2014). Peran UKM dalam Sektor Ekonomi. 6(3), 74-90.

Suhaeni, T. (2018). Pengaruh Strategi Inovasi Terhadap Keunggulan Bersaing di Industri Kreatif (Studi Kasus UMKM Bidang Kerajinan Tangan di Kota Bandung). Jurnal Riset Bisnis Dan Investasi, 4(1), 57. https://doi.org/10.35697/jrbi.v4i1.992

Sumardjo. (2016). Pengertian Komunikasi Inovasi. Komunikasi Inovasi, (Sumardjo 2014), 160.

Suwarno, Y., \& Lan, S. (2018). Bab I Mengenal Inovasi. (December 2016).

Yanuar, R. (2020). No Title. Ayoyogya.Com. Retrieved from https://m.ayoyogya.com/read/2020/07/21/39854/59-persen-umkm-jogja-mati-surikarena-pandemi 